\title{
The range of pasture species in New Zealand and their use in different environments
}

\author{
J.F.L. CHARLTON and B .R. BELGRAVE \\ AgResearch Grasslands, Private Bag 11008, Palmerston North
}

\begin{abstract}
The 29 different species of pasture plants, now commercially available to farmers in New Zealand, may make the choice of pasture seeds and seeds mixtures much more complicated, but their particular features can add significant value to farming. The suitability of these species is presented for the main categories of New Zealand's pastoral land: summer-moist lowland, cast coast dryland, hill country, and the South Island's high country. Important features of each species are summarised. Invested returns from animal production on modem pastures can be more than $200 \%$. However, farmers are advised to seek specialist advice before they invest
\end{abstract}

Keywords species, environment, suitability, compatibility

\section{Introduction}

Twenty-four different species of pasture plants bred in New Zealand, and five imported species. are now available to farmers from seed retailers (Table 1). Most can be regarded as being 'new' to the grassland farming industry (Rumball 1984). Within these species. the current catalogues include55 New Zealand-bred pasture cultivars and 23 overseas cultivars.

Therange has been augmented inrecentyears by the release of improved cultivars of the established pasture species, mainly ryegrasses and clovers. Private plant breeding has been encouraged by plant variety rights, which enables plant breeders to obtain a return on their efforts, and the development of proprietary marketing of pasture cultivars, whereby a company has exclusive sales of a particular cultivar. providing farmers with more technical support from the head licensee.

For the farmer, the choice of pasture seeds and seeds mixtures has become much more complicated during recent years. because of the rapid increase in numbers of species and cultivars. At the same time, the economic downturn in farming, and climate extremes such as drought, have made the choice of suitable seeds mixtures much more important.

This paper aims to inform those selling and using these species about their suitability for the different grassland environments in this country. A previous paperdescribedsome basicconcepts for using species in pasture seeds mixtures on the farm (Charlton 1992). Twenty species that are most widely available are discussed, the others being considered to be either for lilted special-purpose use or currently very limited in seed availability (Table 1).

\section{Use of species}

A survey of farmers (Belgrave et al. 1990) revealed that farmers knew much about familiar species such as ryegrasses and clovers. but little of recently introduced species. Adoption of thesenewer species has beenmuch slower (Lancashire 1985).

On-farm demonstrations were reported by Belgrave et al. (1990) to be the best means of informing farmers of the success of new species in their own area. This concept was adopted in the recent drought relief programmes in cast coast regions of both South and North Islands (Milne \& Fraser 1991). Demonstration paddocks of the drought tolerant species in mixtures were established and used for technology transfer. As a result of this approach, the adoption rate of these species has increased dramatically in a very short period.

Proprietary marketing of pasture species and cultivars has developed during recent years, and head licensees now provide the farmer and the seed retailer with better technical information on aspects of their new herbage cultivars.

\section{Extending the species range}

In the early years of pastoral research, plant scientists such as Levy (1933) emphasised the use of only the best species. in particular perennial ryegrass and white clover. Levy's concept was baaed on the availability of cheap fertiliser. especially superphosphate, and the wide adaptability of these two species (Burgess 1987). They were cheap to buy, established very rapidly and easily, and were adapted to a wide range of management systems.

This concept worked well during the prosperous period after Word War Il. But when the plant breeders during this pcriod realised that other herbage species 
Table 1 Species of pasture plants commercially available to farmers in New Zealand in 1992. Those species asterisked have very limited seed availability at present, or are only for restricted use in special situations.

\section{Legumes}

white clover (Trifolium repens)

Red clover (Tritolium pratense)

Strawberry clover (Trifollum fragiterum)*

Lotus (Lotus uliginosus syn L pedunculatus )

Birdsioot trefoll (Lorus comiculatus)

Lucerne (Medfcago sativa)

Serradella (Omithopus satívus)"

Sulla (Hedysarum coronarium) ${ }^{*}$

Herbs

Chicory (Cichorum Intybus)

Sheep's bumet (Sanguistuba minor)

\author{
Crasses \\ Perennial ryegrass (Lolium porenne) \\ Italian ryegrass ( $L$ mutifforum) \\ Hybrid ryegrass (L boucheanumsyn L hybrfdum) \\ Cocksfoot (Dactylls glomerata) \\ Tall fescue (Fostuca arundinacea) \\ Phalarts (Phalaris aquatica) \\ Pralite grass (Bromus wildinowil) \\ Grazing brome (Bromus stamineus) \\ Smooth brome (Bromus inermis \\ Upland brome (Bromus marginatus \\ Timothy (Phleum pretense) \\ Browntop (Agrostls capillaris) \\ Yorkshire fog (Holcus lanatus) \\ Paspalum (Paspalum dilatatum)"
}

Imported spacles

Subterranean clover (Trifolium subterraneum)

Alsl ke clover (Trifolium hybridum )

Perennial necorn (Secale delmallicum)

Pubescent wheat grass (Agropymn trichophorum)"

Oat grass (Armenatherum elatius) *

offered particular features which could extend the economic base of this country's pastoral farming. they started breediig improved varieties of some of the other grasses and legumes considered to have potential.

DSIR Grasslands consequently released several new species during the 1970s andearly 1980s, such as prairie grass, lotus, tall fescue, phalaris, smooth brome grass. and upland brome grass.

Other species have been added to the list in recent years, including chicory, grazing brome grass, strawberry clover, birdsfoot trefoil, sulla, serradella, browntop, sheep's bumet and paspalum. These species were released because they had particular combinations of features which add significant value to pasture for animal farming in some particular way. Some, such as paspalum, serradella and strawberry clover, have more potential for export to countries such as Australia.

During the same period, improved varieties of the more conventional species were released, including varieties of ryegrasses. cocksfoot, red clover and white clover.

\section{Suitability of species for farming}

We have graded the relative suitability of all these species for the five main categories of New Zealand's pastoral land - summer-moist lowland, cast coast dryland, the North Island's moist hill country,dry hill country. and the SouthIsland's high country (Table 2). Some species are highly suited to each particular pasture environment. Recommended species are printed in bold, in both the text and in Table 2. Table 3 shows the major features of each species, given its overall suitabil- ity for that particular pasture environment. Table 4 shows the relative seasonal production of each species, which is perhaps the most valuable feature of the range. Plant breeders have encountered difficulty with increasing total annual yield of pasture, whereas seasonal yield increases are still possible and necessary, to add value to the farm production base.

\section{Species for summer-moht lowland}

The fertile, intensively farmed pastures support dairying, sheep and beef fishing, deer farming, and other livestock types such as thoroughbred horses. This is the prime grazing land of the country, where the species developed in the early years remain the most valuable . the ryegrasses, cocksfoot, red clover and white clover (Harris \& Chu 1985; Goold et al. 1985). Timothy has traditional use in the warm, moist summers of southern South Island regions, particularly where pasture is conserved as hay or silage. but fails to persist in drier summers further north. In recent years, new species such as chicory, tall fescue, phalaris and prairie grass have been shown to be valuable additions to the range of species for mixtures.

Dairying. The first choice for dairy pastures is perennial ryegrass and white clover. These species give highly productive pasture of excellent quality in most regions where dairying is practised. They are fast and relatively easy to establish on such fertile soils. A wide range of varieties of both species is now available, so those bred to suit dairying should be chosen and used, eg Grasslands Kopu white clover. Some varieties of ryegrass with high levels of the endophyte fungus can 
Table 2 Suitability of available pasture species to the main pasture environm ents in New Zealand (Scale: 5 -high: 1 low, recommended spocies In bold).

\begin{tabular}{lcccc}
\hline SPECIES & $\begin{array}{c}\text { Summer-moist } \\
\text { lowland }\end{array}$ & Dryland* & $\begin{array}{c}\text { North Island } \\
\text { moist hill } \\
\text { country }\end{array}$ & $\begin{array}{c}\text { Dry hill } \\
\text { country }\end{array}$ \\
\hline
\end{tabular}

\section{Grasses}

\section{Ayegrasses:}

Perennial jegrass

Hybrid ryegrass

Cocksfoot

Tail fescue

Phalaris

Brome grasses:

Prairie grass

Grazing

Smooth

Upland

Browntop

Yorkshire fog

5
5
5
3
3
2
4
3
1
1
1
1

3
1
1
5
5
5

$\begin{array}{rr}3 & \\ 2 & \\ 5 & \\ 2 & 4\end{array}$

$\begin{array}{ll}2 & 1 \\ 2 & 1 \\ 1 & 1 \\ 5 & 4 \\ 3 & 3 \\ 5 & 2\end{array}$

Legumes

Red clover

Lucerne

Lotus

Birdsloot trololl

Sub clover

5
5
3
1
3
2

4
5
2
3
3
2

2
5
3
2
5
4

\section{2}

5

Herbs

Chicory

Sheops bumet

5

2
3
4
2
5
5

4
2
1
5
1
4

$\begin{array}{ll}3 & 2 \\ 4 & 4 \\ 2 & 2 \\ 2 & 4 \\ 2 & 4 \\ 5 & 1\end{array}$

- When irrigated, refer to summer-moist lowland.

- Newer cultivars selected for this situation will perform best.

Table 3 Major characteristics of the pasture species currendy available in N ew Zealand( $5=$ high; $1=$ low).

\begin{tabular}{|c|c|c|c|c|c|c|c|c|c|}
\hline SPECIES & $\begin{array}{c}\text { Fertility } \\
\text { neods }\end{array}$ & $\begin{array}{l}\text { Heavy soll } \\
\text { tolerance }\end{array}$ & $\begin{array}{l}\text { Drought } \\
\text { tolerance }\end{array}$ & $\begin{array}{c}\text { Insect } \\
\text { tolerance }\end{array}$ & $\begin{array}{l}\text { Mixture } \\
\text { compati } \\
\text { bility }\end{array}$ & $\begin{array}{c}\text { Ease of } \\
\text { Establish- } \\
\text { ment }\end{array}$ & $\begin{array}{c}\text { Ease of } \\
\text { menage- } \\
\text { mea }\end{array}$ & $\begin{array}{l}\text { Animal } \\
\text { eccep- } \\
\text { tance }\end{array}$ & $\begin{array}{l}\text { Porsile } \\
\text { tence }\end{array}$ \\
\hline \multicolumn{10}{|l|}{$\begin{array}{l}\text { Graeaee } \\
\text { Ryegrasses: }\end{array}$} \\
\hline Perennial ryegrass & 3 & 3 & 2 & 3 & 3 & 5 & 4105 & 3 & 4 \\
\hline Hybrid ryegrass & 4105 & 3 & 1 & 2 & 4 & 5 & 3 & 4 & 3 \\
\hline Italian ryegrass & 4 & 3 & 1 & 1 & 4 & 5 & 3 & 4 & 2 \\
\hline Cocksfoot & 1102 & 2 & 4105 & 3 & 2 & 4 & 3 & 3 & 5 \\
\hline Tall fescue & 4 & 5 & 4 & 4 & 3 & 2 & 4 & 3104 & 5 \\
\hline Phalaris & 1 & 3 & 5 & 5 & 4 & 3 & 3104 & 3 & 5 \\
\hline \multicolumn{10}{|l|}{ Brome grasses: } \\
\hline Prairie grass & 4105 & 1 & 3 & 3 & 2 & 3104 & 1 to 2 & 4 & 3 \\
\hline Grazing & 3 & 2 & 4 & 3 & 3 & 3104 & 3 & 4 & 4 \\
\hline Smooth & 2 & 2 & 3 & 3 & 3 & 2 & 3 & 4 & 4 \\
\hline Upland & 3 & 2 & 3 & 3 & 3 & 3 & 3 & 4 & 2 \\
\hline Browntop & 2 & 3 & 3 & 3 & 3 & 3 & 3 & 3 & 5 \\
\hline Yorkshire fog & 2 & 4 & 3 & 4 & 2 & 3 & 3 & 4 & 3 \\
\hline \multicolumn{10}{|l|}{ Legumes: } \\
\hline Whilte clover & 4 & 4 & 2 & 3 & 4 & 3104 & 4 & 4 & $\mathbf{5}$ \\
\hline Red clover & 4 & 3 & 4 & 3 & 4 & 4 & 4 & 5 & 2 \\
\hline Lucerne & 4 & 1 & 5 & 3 & 2 & 3 & 3 & 4 & 2 \\
\hline Lotus & 2 & 4 & 3 & 3 & 1 to 2 & 2 & 3 & 3 & 5 \\
\hline Birdstoot trafoil & 2 & 2 & 5 & 3 & 1102 & 3 & 3104 & 4105 & 2 \\
\hline Sub clover & 2 & 1 & 1 & 3 & 4 & 4 & 4 & 4 & 4 \\
\hline \multicolumn{10}{|l|}{ Herbs } \\
\hline Chicory & 4 & 1 & 4 & 4 & 3104 & 4105 & 4 & 5 & 2 \\
\hline Sheeps burnel & 2 & 2 & 4 & 3 & 1 to 2 & 2103 & 4 & 3 & 3 \\
\hline
\end{tabular}


Table 4 Seasanal growth of New Zealand pasture species (Scale 1 fopor to nil, 3=good).

\begin{tabular}{lcccc}
\hline SPECIES & $\begin{array}{c}\text { Summer } \\
\text { growth }\end{array}$ & $\begin{array}{c}\text { Autumn } \\
\text { growth }\end{array}$ & $\begin{array}{l}\text { Winter } \\
\text { growth }\end{array}$ & $\begin{array}{c}\text { Spring } \\
\text { growth }\end{array}$ \\
\hline
\end{tabular}

\section{Grasses:}

Ryegrasses:

Pyere $n$ i a I regrass
Hybrld ryegrass
Italian yegrass
Cocksfoot
Tall fescue
Phalaris
Brome grasses:
Prairle grass
Grazing bmme
Smooth bmme
Upland brome
Srowntop
Yorkshire tog

\section{Legumes:}

White clover

Red clover

Lucerne

Lotus

Birdsfool trefoil

Sub clover

\section{Herbs}

Chicory

Sheep burnet

3

- Values for newer cutivars selected especially for impmved seasonal gmwth in brackets.

suppress clover growth (Sutherland \& Hoglund 1989). Addition of cocksfoot and/or phalaris to a perennial ryegrass/clover seeds mixture can improve animal performance in some situations (Moloney 1992).

Italian ryegrass and hybrid ryegrass are also used widely by dairy farmers who may need extra herbage of top quality in the cooler seasons. Chicory offers considerable advantage as a very high quality forage to boost feed supply when ryegrass growth is slow, in mid to late summer. Dairy farming has recently developed in some regions not traditionally known for this industry, such as South Canterbury and Southland. In these regions, the choice of species for the most suitable pastures may need to be different from those in existing grassland, especially in terms of cultivsr type.

Meat production The extended species range is proving most valuable for farmers in finishing. as it can providepasturesmore suited to seasonalneeds, enabling liveweight deadlines to be met more easily. Farmers are now more able to select a pasture species mixture that boosts meat production and quality. As in dairying, perennial ryegrass, hybrid ryegrass, Italian ryegrass, white clover and red clover are the most popular species for meat production pastures. Chicory has become a favourite species. giving faster growth rates in sheep. cattle and deer. Up to three times as many lambs can be carried during summer when grazing chicory, and growths can be up to twice as fast as on ryegrass pastures (G. Milne, pers. comm.). Selling stock earlier can boost levels of winter feed. With as little as $5 \%$ of their farms in chicory, some farmers have lifted average lamb carcass weights by $2 \mathrm{~kg}$. Deer farmers can meet liveweight targets much earlier with new pastures containing red clover, chicory and Westerwolds ryegrass, compared with their existing perennial ryegrass-based pastures. The short-lived ryegrass boosts winter pasture growth (W. F. Hunt, pers. comm.).

Pastures for racehorses should not contain much ryegrass with high endophyte levels, because of the long term effect that the disorder ryegrass staggers can have on their racing performance (T. Field, pers. comm.). Grasses such as prairie grass and cocksfoot are preferable for horse paddocks, used along with white clover and chicory (Hunt \& Hay 1990).

\section{Species for dryland}

The pastures of eastern regions regularly suffer seasonal droughts. which can be much more extensive in some years, yet these regions can also suffer flood and storm damage, especially the eastern North Island. One of the worst droughts on record occurred in 1989-1990, and this showed the value of species other than shallowrooted ryegrass. Additional stress is exerted on droughthit pastures by pests such as grass grub and Argentine stem weevil, whose attack coincides seasonally with drought. After the 1989-1990 drought, many dryland pastures were seen to consist largely of low-producing grasses such as crested dogstail (Cynosurus cristatus) and sweet vernal (Anthoxanthum odoratum) which are very early flowering and produce copious quantities of seed, enabling them to survive the dry summers.

The newer perennial grasses are now alternatives to the traditional perennial ryegrass in these situations (Rumball 1983; MacFarlane 1991). Tall fescue, cocksfoot and phalaris in mixture together are proving most effective in regions where dry summers, pasture pests and ryegrass staggers threaten milk production (Moloney 1992). Tall fescue has became more popular as an alternative perennial grass to ryegrass since the last drought, as it increases summer feed production (Brock 1983). Not only is it mom productive during summer, but its herbage remains green and very acceptable to grazing stock. It is also mom compatible with clovers than ryegrass, and tolerates grass grub and drought better, once it is established. Addition of phalarls to mixtures for dryland has proved beneficial, especially when combined with cocksfoot. Together in mixture, these two grasses have increased pasture production significantly in east coast dryland, and the two species are compatible for use on less fertile soils in dry hill country. 
Prairie grass is the most winter active perennial grass, but needs free-draining, high fertility soils and more Careful grazing management (than for existing pasture) foroptimumperformance (Fraser 1985). Grazing brome is showing high potential for closer grazed pastures in dryland regions of the east coast. Attack by hessian fly in northern North Island pastures may affect persistence.

Lucerne remains a most valuable legume for fertile dryland pastures. Red clover has been shown to be valuable for deer farming, as it meets summer feed demands(Hunt \& Hay 1990). Subterranean clover should be used for finishing pastures where it provides winter and early spring feed. Birdsfoot trefoil has good potential as alucemereplacement for less fertile dryland soils, without any danger of causing bloat (Scott \& Charlton 1983).

Chicory boosts feed supplies for all types of livestock systems during spring, summer and autumn on fertile dryland soils. It can be used in mixture with only clovers, or can be a component of grass-clover mixtures.

When dryland pastures are irrigated, then the species recommended for summer-moist lowland should be used.

\section{Species for hill country}

A large area of hill country has been developed for animal farming, aided by aerial oversowing with perennial ryegrass and white clover and topdressing. However, much of the pasture on this land comprises lower fertility species such as browntop. Yorkshire fog, sweet vernal and crested dogstail (Charlton 1984). Aerial topdressing. to maintain the ryegrass-based pastures. declined significantly during the 1980 s as fertilisercosts escalated. Pasture renewal in North Island hill country almost ceased after subsidies were withdrawn.

Since then. farmers have limited reseeding to their improved, more fertile pastures, using the species mentioned in the section on summer-moist lowland. In such situations where fertiliser can be applied easily. perennial ryegrass, cocksfoot and white clover mixtures are still appropriate (Chapman \& Macfarlane 1985).

Newer species with potential use in less fertile, unploughable hill pastures include cocksfoot (especially the dense, prostrate Grasslands Wana variety), phalaris (always in mixture with other grasses, especially cocksfoot), browntop and grazing brome, especially in drier east coast regions (Table 2). Legumes for these pastures including white clover (especially Grasslands Tahora and Grasslands Prestige, bred for less fertile closely-grazed sheep pastures), subterranean clover, and lotus (Grasslands Maku and Grasslands Sunrise)

\section{Species for South Island high country}

Large areas of extensive animal farming in highcountry experience hot. dry summers and cold winters. They generally supported tussock grasslands before colonisation began. Farming is mainly extensive. with improvement of smaller areas near the homesteads. In recent years, invasion by rabbits and the flatweed Hieracium has severely limited pasture renewal.

A wide range of pasture species has been evaluated in this environment, and plant breeding programmes have been conducted by joint MAF/DSIR teams. Species used for this environment to date include grasses such as smooth brome. upland brome. the legumes lotus, birdsfoot trefoil, alsike clover (Trifolium hybridwn), and lupin (Lupinus) species, and herbs such as sheep's burnet. Scott $\boldsymbol{e} t$ al. (1985) gave a detailed account of species in these situations. For pasture renewal of improved flatland pastures. perennial ryegrass, cocksfoot, whlte clover, red clover, birdsfoot trefoil and lucerne are important species.

\section{Summary}

New Zealand now has a more suitable range of pasture species available to meet current needs. By careful selection of pasture component species from the increased range, value can be added to animal production systems when pasture is renewed. The invested returns from animal production on modem, productive pastures can be more than $200 \%$, based on an average renewal cost of $\$ 350$ per hectare (G. Milne, pers. comm.). However, the increased range of species also makes decisions more difficult. and farmers are advised to seek specialist advice before they invest.

\section{REFERENCES}

Belgrave, B.R.; Watt, P.C.; Brock, J.L.; Wewala, S.; Sedcole. J.R. 1990. A survey of farmer knowledge and use of pasture cultivars in New Zealand. NZ journal of agricultural research 33: 199-211.

Brock, J. L. 1983. 'Grasslands Roa' tall fescue: A review. Proceedings of the NZ Grassland Association 44: 74-80.

Burgess, R.E. 1987. The development of our plant resources: then and now. Proceedings of the $\mathrm{NZ}$ Grassland Association 48: 89-92.

Chapman, D.F.; Macfarlane, M.J, 1985. Pasture growth limitations in hill country and choice of species. In "Using Herbage Cultivars" Grassland Research and Practice Series No. 3, New Zealand Grassland Association : 25-30. 
Charlton. J.F.L. 1984. Persistence of 'Grasslands Huia' white. clover (Trifolium repens L) in hill country pastures. Proceedings of the NZ Grassland Association 45: 131-139.

Charlton. J.F.L. 1992. Some basic concepts of pasture seeds mixtures for New Zealand farms. Proceedings of the NZ Grassland Association 53: 37-40.

Fraser, T.J.1985. Role of Matua prairie grass in an allgrass system for prime lamb production. Proceedings of the NZ Grassland Association 46: 157-161.

Goold, G.J.; Thomson, N.A.; Duder, F.R. 1985. Agronomic and environmental constraints in North Island dairying and the choice of pasture species. In "Using Herbage Cultivars" Grassland Research and Practice Series No. 3, New Zealand Grassland Association :67-70.

Harris. A.J.; Chu. A.C.P. 1985. Limitations to production and choice of species in finishing pastures. In "Using Herbage Cultivars” Grassland Research and Practice Series No. 3, New Zealand Grassland Association :53-58.

Hunt, W.F.; Hay, R.J.M. 1990. A photographic technique for assessing the pasture species preferences of grazing animals. Proceedings of the NZ Grassland Association 51 191-196.

Lancashire, J.A. 1985. Factors affecting the adoption of new herbage cultivars. In "Using Herbage Cultivars" Grassland Research and Practice Series No. 3, New Zealand Grassland Association: 79-88.

Levy, E.B. 1933. Strain development in herbage plants. Proceedings of the NZ Grassland Association 2:7275.

MacFarlane, A.W. 1991. Field experience with new pasture cultivars in Canterbury. Proceedings of the NZ Grassland Association 52: 139-144.

Milne, G.; Fraser, T.J. 1991. Establishment of 1600 hectares in dryland species around Oamaru/Timaru. Proceedings of the NZ Grassland Association 52: 133-138.

Moloney. S. C. 1992. Performance of tall fescue, cocksfoot and phalaris based pastures compared with perennial ryegrass, in on-farm trials.Proceedings of the NZ Grassland Association 53: 41-46.

Rumball, W. 1983. Breeding for dryland farming. Proceedings of the NZ Grassland Association 44: 5660.

Rumball, W. 1984. New plants for New Zealand pastures. Proceedings of the NZ Institute of Agricultural Science 18: 127-129.

Scott, D.; Charlton. J.F.L. 1983. Birdsfoot trefoil (Lotus corniculatus) as a potential dryland herbage legume in New Zealand. Proceedings of the NZ Grassland Association 44: 98-105.
Scott, D.; Keoghan,J.M.; Cossens, G.G.; Maunsell,L.A.; Floate, M.J.S.; Wills, B.J.; Douglas, G. 1985. South Island hill and high country. Limitations to pasture production and choice of species. In "Using Herbage Cultivars' 'Grassland Research and Practice Series No. 3. New Zealand Grassland Association: 9-15.

Sutherland, B. L.; Hoglund, J. H. 1989. Effect of ryegrass containing the endophyte Acremonium lolii, on the performance of associated white clover and subsequent crops. Proceedingsof the NZ Grassland Association 50: 265-269. 